\title{
The Opining Mining of Expatriate Adjustment and Significant Role of Social Media
}

\author{
Benson Nwaorgu ${ }^{1, *}$ \\ ${ }^{1}$ Digitalization Research Group, School of Economics and Business, Kaunas University of Technology, Lithuania \\ *Correspondence: Digitalization Research Group, School of Economics and Business, Kaunas University of \\ Technology, Lithuania. E-mail: benson.nwaorgu@ktu.edu
}

Received: March 25, 2019 Accepted: April 18, 2019 Online Published: April 25, 2019

doi:10.5430/mos.v6n1p42 URL: https://doi.org/10.5430/mos.v6n1p42

\begin{abstract}
In this research paper, the researcher focused on the opining mining of expatriate adjustment and the significant role of social media in real life. It is also one of the significant research issues for the person who are having citizenship of one country and living in another country with a cross-cultural environment. The researcher would identify the factors of a cross-cultural environment which are suitable and significant for the expatriate adjustment with the help of social media. The social media is having of its own significant role in adjusting expatriate with respect to opinion mining. The opinion mining is one of the processes of seeking innovation of ideas and thought on the basis of existing or currently available in the real world. The social media is playing one of the biggest enablers for expatriate in a cross-cultural environment. The objective of this research paper is to identify the factors which are significant with respect to opinion mining and social media in a cross-cultural environment. The researcher emphasized that the reason for online communication with respect to social media that flows are concept and opinion which thus play a significant role in the cohesion and transformation of society. Its minimal concern on the emergence of opinions, widespread, and get benefits. The researcher used the social media for the adjustment with respect to expatriate's adjustment.
\end{abstract}

Keywords: expatriates, social media, adjustment, cross-cultural adjustment

\section{Executive Summary}

This research article is based on the expatriates who are staying different part of different part of countries and too far from their home countries. Beyond their qualification and nature of job, the number of people are having a psychological problem due to language problem, job conflicts, and adjustment with other nature of human being. The researcher emphasized the current research issues and about the significant role of social media to reduce the gap between national culture, behaviors, and adjustment with respect to the nature of job including their family members. The researcher focused on individual factors of expatriates for achievement and social efficiency, relational and perceptional skills, language fluency, job factors, role clarity, and conflicts in different part of the countries.

Keywords: expatriates, social media, adjustment, cross-cultural adjustment

\section{Introduction}

Opinion mining is additionally a kind of tongue methodology for chase the mood of the public one or two of categorical product. Opinion mining that is additionally known as sentiment analysis involves building a system to gather and reason opinions one or two of product. Automatic opinion mining usually uses machine learning, a kind of AI (AI), to mine text for sentiment. Opinion mining is beneficial in many ways that. It's going to facilitate marketers live the success of a commercial campaign or new product launch, check that that versions of a product or place unit widespread and verify that demographics like or dislike categorical product decisions. There is a unit many challenges in opinion mining. The primary is that a word that's thought to be positive in one scenario is, in addition, thought of negative in another scenario. Take the word "long" as an example. If a consumer same a laptop's battery life was long, which can be a positive opinion. If the patron same that the laptop's start-up time was long, 
however, which can be is additionally a negative opinion. These variations mean that associate in mining opinion system trained to assemble opinions on one moderately product or product feature might not perform alright on another.

A second challenge is that folks do not often seek specific opinions in the identical manner. Most ancient text methodology depends on the actual proven fact that tiny variations between two things of text do not modify the suggests that a superb deal. In opinion mining, however, "the image was great" is awfully altogether utterly completely different from "the image wasn't great". Finally, individuals are contradictory in their statements. Most reviews can have each positive and negative comments that are somewhat manageable by analyzing sentences one at a time. However, the additional informal the medium, the additional altogether likelihood individuals square measure to mix altogether utterly completely different opinions at intervals identical sentence. Usually even others have an issue understanding what somebody thought supported a fast piece of text as a result of it lacks context in cross-cultural surroundings.

\section{Literature Review}

Edson Keyso DE Miranda Kubo associate degreed Beatriz Maria metropolis Lacombe(2012 ) stressed on Rethinking adjustment and success in expatriation: an enquiry on Japanese expatriates in Brazil Structured, and showed the Japanese expatriates are thought-about as samples of success in expatriation because of their lowest failure rates within the word (TUNGLI e PEIRPEL, 2009). However, very little is thought concerning however they succeed this success. Per Black et al. (1991), success in expatriation depends upon the intercultural adjustment of the expatriate.

Min Hyounae et al., (2013) emphasized that expatriate society employment programs considerably influence expatriate adjustment has been debated for over twenty years. This paper aims to seem at a crucial variable not nevertheless addressed the emigre's point of view in respect to the company's investment at intervals of use (described as PCTI "perceived company employment investment"). Once degree expatriate boss observes the investment of his/her company in PCTI goes beyond the trade standards, then it finally finishes up in exaggerated task modification. Curiously, PCTI is otherwise seen to considerably impact the expatriate's overall modification at the international culture intervals.

Nana Yaw Oppong (2013) centered on structural adjustment programme (SAP) is that the International money (IMF) and administrative unit agenda for addressing the debt and economic crises of some aggregation countries. To assist countries but, the planet Bank/IMF demand reforms. Victimization preponderantly tutorial and customary literature, and trade information from the Republic of Republic of Ghana Chamber of Mines and administrative unit report on trade, it emerges that the policy has integrated the Republic of Ghana, like fully totally different adjusting African nations, into the world economy and reshaped the gold mining trade. The policy but falls in need of what it had been meant to achieve; rather worsening the things additionally as a detachment of the land government from her own mineral resources; 'subsidiarity' of land gold mining industry; and significant unemployment.

\subsection{Cross-Cultural Adjustment by Expatriates}

Li-Yueh Lee (2010) mentioned that cultural intelligence, and equivalent - emotional intelligence might contribute to their success on foreign assignments, they have a tendency to debate every of those severally. By declarative that every one of those intelligence operates inside expatriates at the same time, this study then examines however they contribute to the success of expatriation. Moreover, this work conjointly investigates beneath what conditions multiple intelligences will enlarge their effects. By adopting a qualitative study approach as well as, in-depth interviews of specialists, employers, and expatriates, this study reveals that the employment of multiple intelligences is contingent upon expatriates' commitment toward the organization, social support, essential interaction, and assignment tenure.

Roblyn patriarch, Keiko Fujiu, (2000) studied that reportable a robust interrelationship between the failure of expatriate and individual modification in international tasks. Since Japanese companies area unit comparatively in at minimizing govt failure rates, to seem at before pre - takeoff arrangement and the Japanese's spouses' behaviors at intervals of the region. Statistical method and regression were accustomed check style of hypotheses. It is therefore obtained from our study that pre-takeoff actions and behaviors had an effect on the spouse's post-arrival modifications. The scientist along their research discovered that most of the Japanese wives benefited from the profit of each source reception (both personal and nonpersonal), and as well from overseas for efficient activity.

Steve McKenna, (2010) explored the thought of expatriate adjustment through gift information. Specifically, through associate investigation of $3 \mathrm{e}$ - mails sent to the author by an acquaintance, Doug, the paper explores the notion that 
adjustment is a fluid construct that through analysis ways that it's realizable to understand the expatriate expertise at intervals the context of associate expatriate's "whole life" of experiences. The e - mails represent a style of gift information, and via varieties of narrative analysis the e - mails area unit able to be examined to throw light-weight on the maneuver of expatriate adjustment. The analysis article highlights ways that $\}$ in that throughout which analysis ways that sometimes, and specifically once utilized in connection expatriates, modify a fuller understanding of the processes of "adjustment" that expatriates expertise and its relationship to their life as a "work in progress".

\subsection{Adjustment}

Vesa Suutari, David Burch, (2001) targeted on international assignments that became lots of standard career approach in the careers act than before. And on the contrary side, many issues such as aboard high prices, untimely returns, inability and challenges modification has been seen to incorporated into expatriation. Based on the outcome of academic degree, the desire for well-planned arrangement and coaching of these expatriates have been fruitless. The foremost target here is on pre-takeoff problems whereas on-the-scene backing and coaching rendered by the hist sections have obviously been coated below par. At intervals of gift research, it's totally analyzed on what on-the-scene backing and the host coaching department will give to the emigres and absolutely what backing is seen as important by the expatriates. Thus, the existing analysis would possibly overstate the shortage of emigre work once concentrating on pre - takeoff work alone.

Kimmo Riusala, Vesa Suutari, (2000) targeted on the link betwixt international task and career building seen specifically to be vague. Also, additional analysis has been attached in conation with difficulty in career and managing of career events of the emigres accordingly. This study covers these problems supported the experiences of expatriates. Career arrangements once come back was a really outstanding matter between expatriates. And on the contrary side, the leads to addition shows that career - related supporting exercise carried out weren't quite standard throughout this pattern. However, obvious irregularity was noticed betwixt ken requisite and the real use of those organized events. Dual - career couples' career problems contend a major part as at intervals the expatriates' case maybe. Notwithstanding, the backing of dual - career wasn't sometimes offered though it absolutely was everywhere once more seen as necessary.

Vesa Suutari, Kusdi Raharjo, Timo Riikkilä, (2002) emphasized that international assignments that became lots of and lots of typical components of a gaggle action career. The goals of this study were to analyses whether or not and conjointly the means that expatriate managers modification their leadership vogue because of cross - cultural variations, and whether or not and conjointly the means that native subordinates understand the forms of expatriate employers not to agree with the forms of native employers once realizable changes. Collection of information was done by Assessment Finnish émigré employers and their subordinates from Indonesia in an actual cross - cultural trade framework with a bicultural examining group.

Jan Selmer, Hon Lam, (2004) expressed that applicants that have the required skills for international tasks are to boot met by erstwhile "third - culture kids". Dominant for the implications previous and gender-specific, outcome revealed teenager expatriates from Britain showcase eminent features regarding their point of views being foreign collectively as their foreign quality choices and results.

Jan Selmer, (1997) stressed that academic degree study of however hosting nation, nationwide subordinates understand the behavior of leaders of the expatriate employers concerning international tasks. Obtained from the survey of 240 intermediate employers in port with expertise of each native employers from China, and managers of the expatriates from a wide range of Asian and Western countries, discover that their attached lower ranked employers examined the administrative prowess of their expatriate employers to be considered absolutely utterly totally different from that of their Chinese bosses. North American nation of America bosses were perceived as a result of the foremost absolutely utterly totally distinct and Japanese employers as employers from different countries in Asia were seen as a result of the tiniest quantity absolutely utterly totally different, whereas British employers and managers from varied Western nations discovered a middle cluster.

Jaime Bonache, (2005) emphasized on empirical analysis of job satisfaction among expatriates, repatriates, and domestic workers with no international expertise. The analysis study was conducted on an academic degree giant sample of workers from a Spanish international construction company. One - way analysis of variance (ANOVA) so the Scheffe take a look at were utilized to analyses the info. Once dominant for stratified standing, the results indicated that, among these 3 teams of workers, there are a unit some necessary variations at intervals the satisfaction ratings on job characteristics, career prospects, and internal communication. 
Chenyi Qin, Yehuda Baruch, (2010) explored the importance of different cultural background at work and the long-term goals attitudes on the future move in expatriation at intervals with regards to China. Whether or not, cross - cultural work is perceived necessary, so the consequence of providing such cross - cultural work, whereas the impact of cross - cultural work before departure wasn't statistically necessary, it absolutely was well received and regarded necessary. A limitation is that the restricted sample size - implications area unit is given for conducting cross - cultural work.

Julia Richardson, Steve McKenna, (2006) targeted on self - motivated move in expatriates' communication with their domicile associated host countries which reflect on academic degree model in existence that is associated with adherence of expatriates' employers to their residence and host organizations. Employing a qualitative approach and thematic analysis, that it uses a tile presently under - researched theme associated, make provision for academic degree perception into the famous level of autonomous relationship that existed between the expatriates, their abodes and the host nations.

Hung wen Lee, Ching - Hsiang Liu, (2007) emphasized that the challenge of repatriate turnover by specializing in however effective homecoming adjustment, job satisfaction, and structure commitment area unit at predicting the Taiwanese repatriates' intentions to depart their organization. By building on the cross - cultural adjustment and turnover theories and researches, this study expands these recent findings to Taiwanese repatriates. The empirical proof that homecoming modification, employment contentment, and structure engagement area unit undesirably associated with the purpose to depart the establishment. What's further, the abstract identification and categorization of this research is guidance to subsequent analysis in repatriates' turnover purpose.

Ma magnoliopsid genus Taurus author, Raquel Saenz Valle, Ma Isabel Barba Aragón, (2010) the research worker analyzed the homecoming adjustment technique of international staff at intervals the Spanish context. The research analysis further gives proof of the connectedness of making repatriates' modification easy, as a result of it having an effect on their achievement. The research collectively indicates that some factors will make the plan of action easier. Specifically, during the period of expatriation, possession of a wise and trusted counselor and incessantly contacting of home has helped repatriate gain confidence and hope, which afterward, have an impression on their overall modification. Social capability undeniable made it clear that the repatriates had not changed whole international collectively facilitate amendment.

Lyn Glans, (2003) stressed that Two - thirds of European organizations area unit exploitation informal briefings for expatriates. Why have to be compelled to be compelled to expatriates place a serious premium on such input, even once given at intervals the stories of strangers? This text uses a narrative technique to seem at expatriate expertise, considering however stories modify expatriate understanding of novel environments. It considers, in brief, the importance of surprise during this stuff and Weick's seven properties of sense creating area unit used as gospel for putt such expatriate stories throughout the simplest way creating context. It additional queries whether or not or not or not such stories may contribute to skilled development by serving to bestow that suggests for expatriates reflective on their experiences.

Li-Yueh Lee (2018) targeted on expatriates success in foreign assignment is that the final word purpose for headquarter work, significantly to need the care of the performance of the subsidiary at intervals the world market. Among others, society adjustment has been widely accepted reciprocally of the dominate expatriates' performance. Recently, the results of I.Q. (cognitive intelligence), equivalent (emotional intelligence) and CQ (cultural intelligence) area unit evaluated wide. This study intends to suit this analysis gap and integrate relevant antecedent constructs of expatriate adjustment and performance into a comprehensive model the professors and collectively former expatriates, one business executive UN agency was the user of expatriates in additional than eighty countries, and expatriates or former expatriates.

Hon Lam, Jan Selmer, (2004) researchers targeted on UN agency have lived a minimum of one altogether their childhood in another nation. Thus, this research makes a comparison between the data and information obtained from British TCKs UN agency that currently live in Hong Kong during their survey and those teenagers that lives at the intervals of the UK and Hong Kong. Quite the opposite teenagers, it was indicated by TCKs that foreign expertise, parents and institutions educational standard, foreign lingo, noninterference, broad-minded and suppleness, character towards varied traditions and systems, respectfulness, ability to tolerate others' behavior and opinions. All these listed above have a significant impact on international reception, approval of non-native lingo, tradition variations, and future inclination.

Alan Fish \& Jack; Wood (2006) emphasized that expatriate staffing practices in twenty Australian business enterprises that have a physical presence at intervals the East Asian business region implications of the issue 
constructs famous would certify the need for a stage-interdependent perspective to expatriate appointments: that's recognizing that every stage of associate expatriate appointment. (i.e., prior to, throughout and following a rendezvous) is effectively joined to every of the various stages. Additionally, that the expatriate appointment is matched to a firm's international business strategy.

\section{Research Objectives}

The researcher expressed that opinion mining is because the process of unstructured knowledge and text knowledge to categories it into some results like positive, negative and neutral or smart, unhealthy and average so that we will predict the merchandise. The opinion because of the personal state of an individual by that he/she will make categorical their personal emotions, ideas, assessments, judgment, and analysis a couple of specific topics. It's the domain of tongue process and text analytics. It turns out the subjective qualities from matter sources. The role of opinion mining with relevancy expatriate victimization, social media is one in every of vital and the many the numerous analysis problems as a result of everybody having totally different perception with relevancy their like and dislikes that area unit significant within the globe.

In this research paper the researcher will cover the following objectives:

1. To identify the factors of opinion mining which are significant for the expatriate.

2. To study the factors of social media which are significant in cross-cultural environment.

3. To identify the comfort zone of the expatriate in cross-cultural environment.

\section{Conceptual Framework of the Research Study}

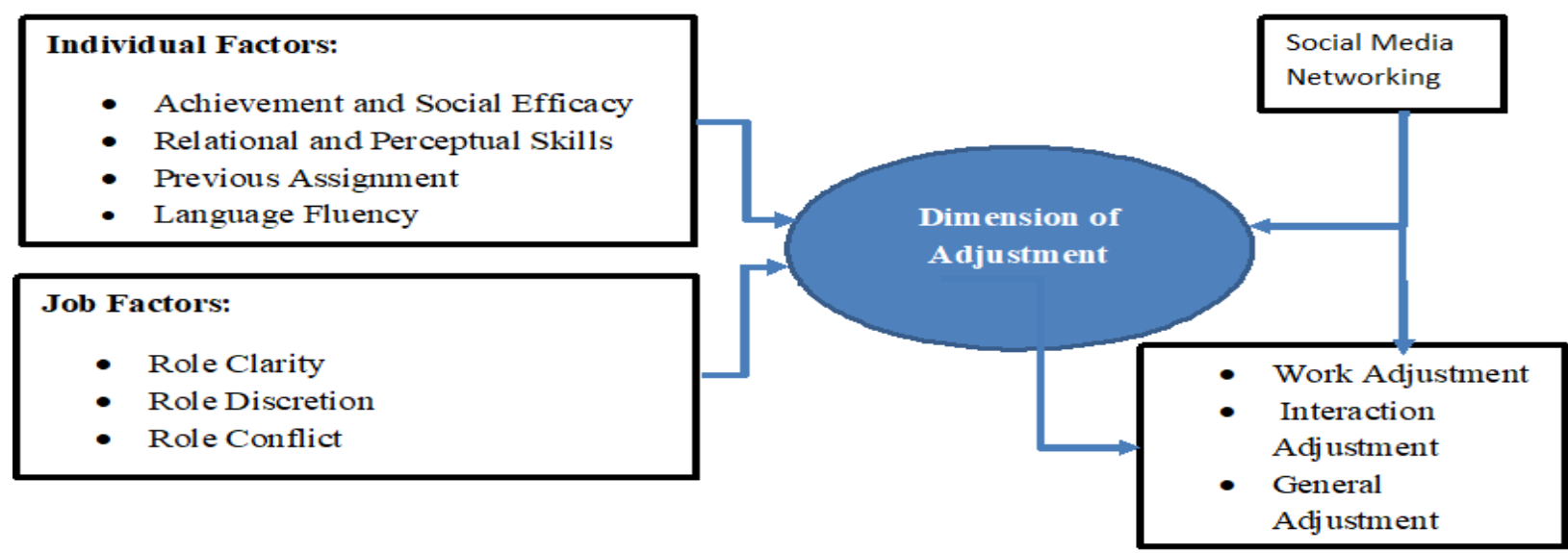

Figure 1. Conceptual Framework of the Research Study

The researcher stated the attributes of the dimension of adjustment which is based on individual factors and job factors. In this research paper, the researcher pointed out the individual and job factors are the independent variables of the dimension of adjustment.

\subsection{Independent Variables}

\section{Independent Variables: Individual Factors}
a) Achievement and Social Efficacy
b) Relational and Perceptual Skills
c) Previous Assignment
d) Language Fluency 


\section{Independents Variables: Job Factors}

a) Role clarity

b) Role Discretization

c) Role Conflict

4.2 Moderating Variables: Social Media

4.3 Dependent Variables: Expatriate Adjustment

\section{Methodology}

This research paper is properly stated with the help of primary and secondary data which are collected from the different research portal and different expatriates who are staying in different countries. They have given their view about the adjustment at different Likert scale. The researcher used the convenience random sampling method to collect the data from different sources of social media, including E-mail, Whatsapp, and structured questionnaire. The researcher also stated some of the hypothesis on expatriates adjustment opinion mining and the significant role of social media. The accuracy of hypothesis is evaluated by decisive the applied mathematics probability that the information reveal true distinction and not sampling error. The Null hypothesis and another hypothesis. To check the hypothesis, the researcher used the SPSS software package to work out the extent of serious with descriptive information analysis.

\section{Data Analysis and Interpretation}

Table 1. Descriptive

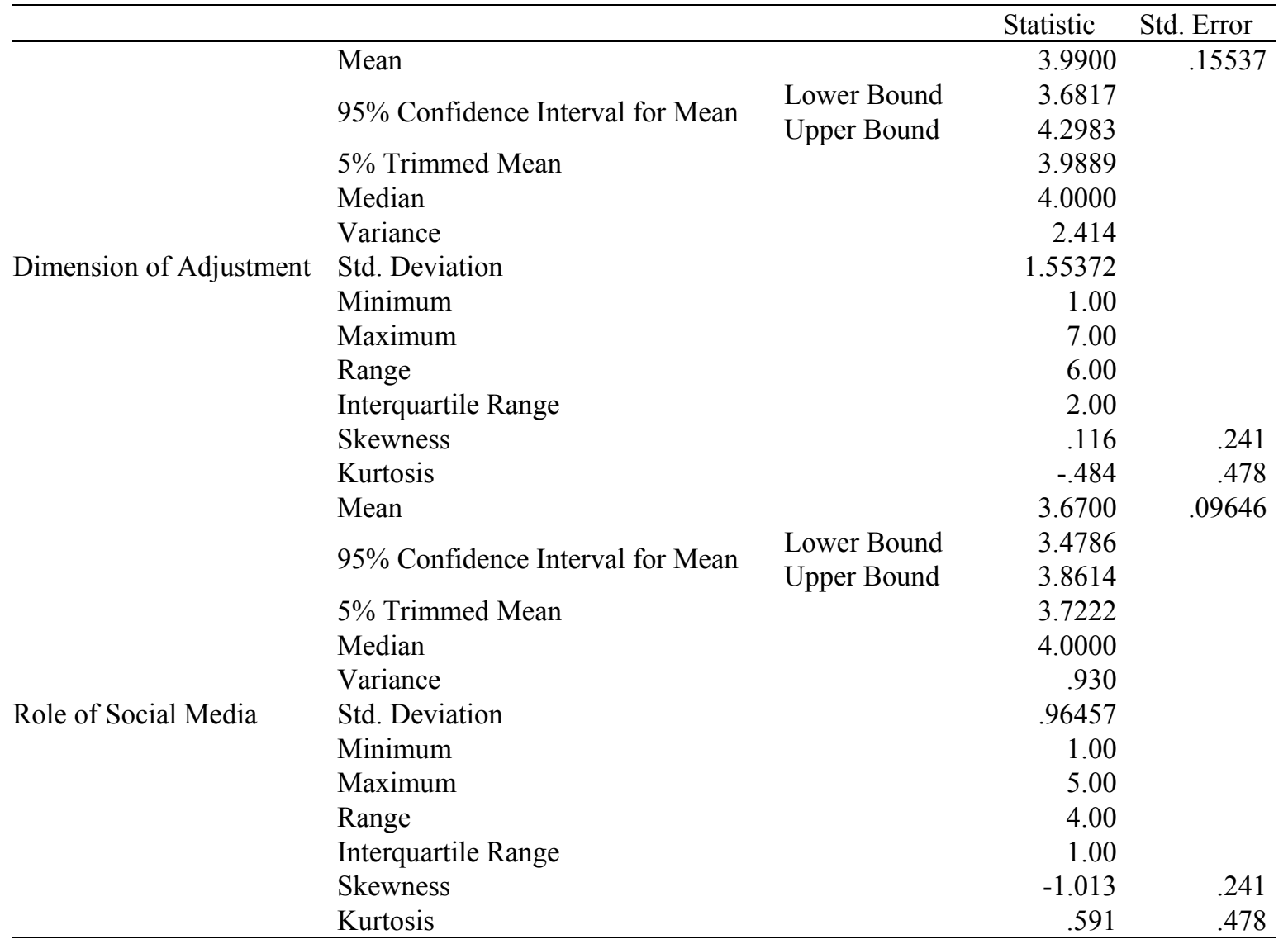


Table 2. Dimension of Adjustment

\begin{tabular}{llrrrr}
\hline & Frequency & Percent & Valid Percent & $\begin{array}{c}\text { Cumulative } \\
\text { Percent }\end{array}$ \\
\hline Valid & & & & 5.0 \\
& General Adjustment & 5 & 5.0 & 5.0 & 19.0 \\
& Interaction Adjustment & 14 & 14.0 & 14.0 & 34.0 \\
Work Adjustment & 15 & 15.0 & 15.0 & 69.0 \\
Psychological Adjustment & 35 & 35.0 & 35.0 & 81.0 \\
Socio-emotional Support Availability & 12 & 12.0 & 12.0 & 93.0 \\
Instrumental Support Needs & 12 & 12.0 & 12.0 & 100.0 \\
Emotional Support Needs & 7 & 7.0 & 7.0 & \\
Total & 100 & 100.0 & 100.0 & \\
\hline
\end{tabular}

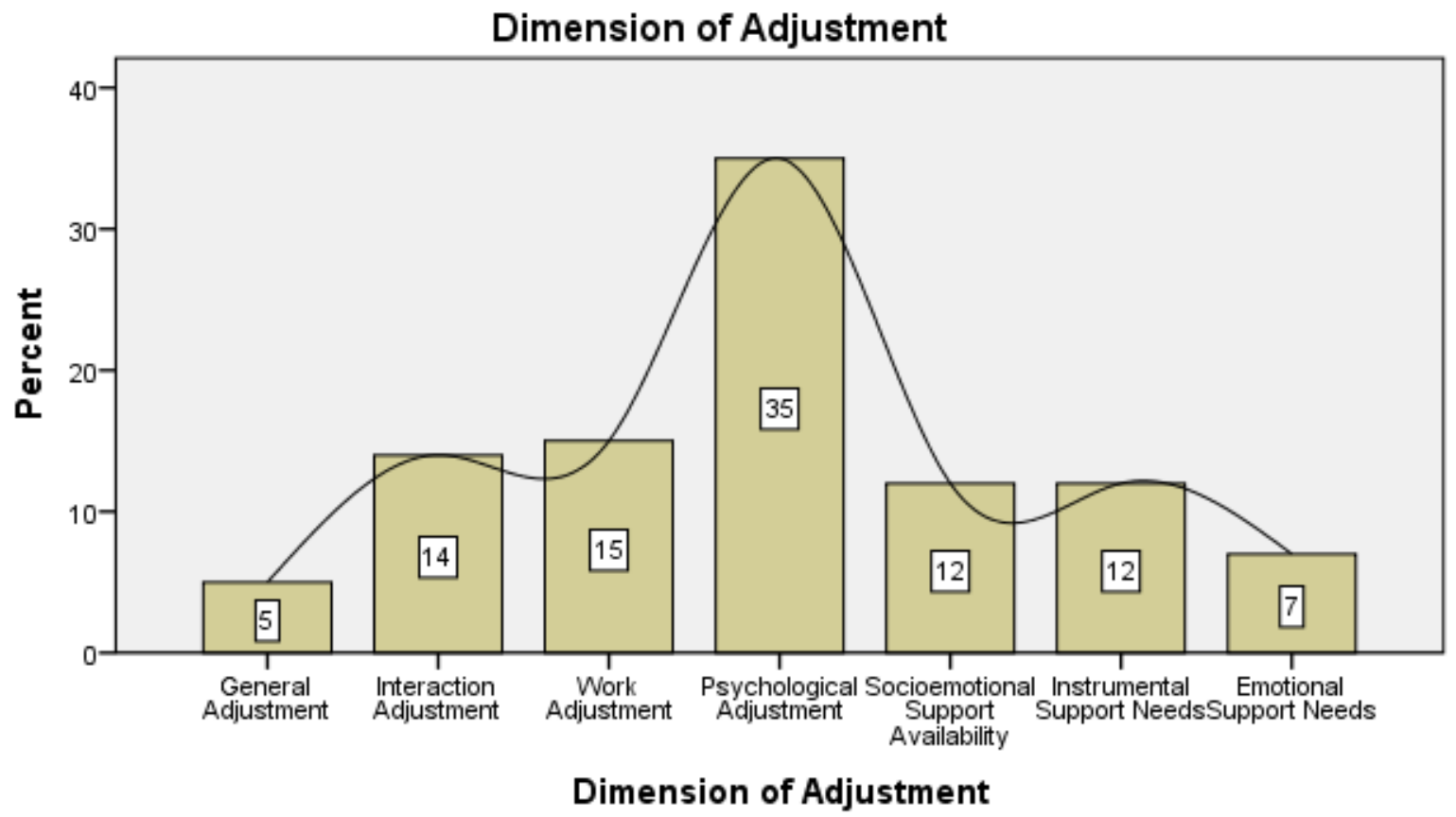

Figure 1. Dimension of Adjustment

Table 3. Role of Social Media

\begin{tabular}{|c|c|c|c|c|c|}
\hline & & Frequency & Percent & Valid Percent & $\begin{array}{c}\text { Cumulative } \\
\text { Percent }\end{array}$ \\
\hline \multirow{6}{*}{ Valid } & Strongly Rejected & 3 & 3.0 & 3.0 & 3.0 \\
\hline & Rejected & 13 & 13.0 & 13.0 & 16.0 \\
\hline & Neither Accepted Nor Rejected & 11 & 11.0 & 11.0 & 27.0 \\
\hline & Accepted & 60 & 60.0 & 60.0 & 87.0 \\
\hline & Strongly Accepted & 13 & 13.0 & 13.0 & 100.0 \\
\hline & Total & 100 & 100.0 & 100.0 & \\
\hline
\end{tabular}




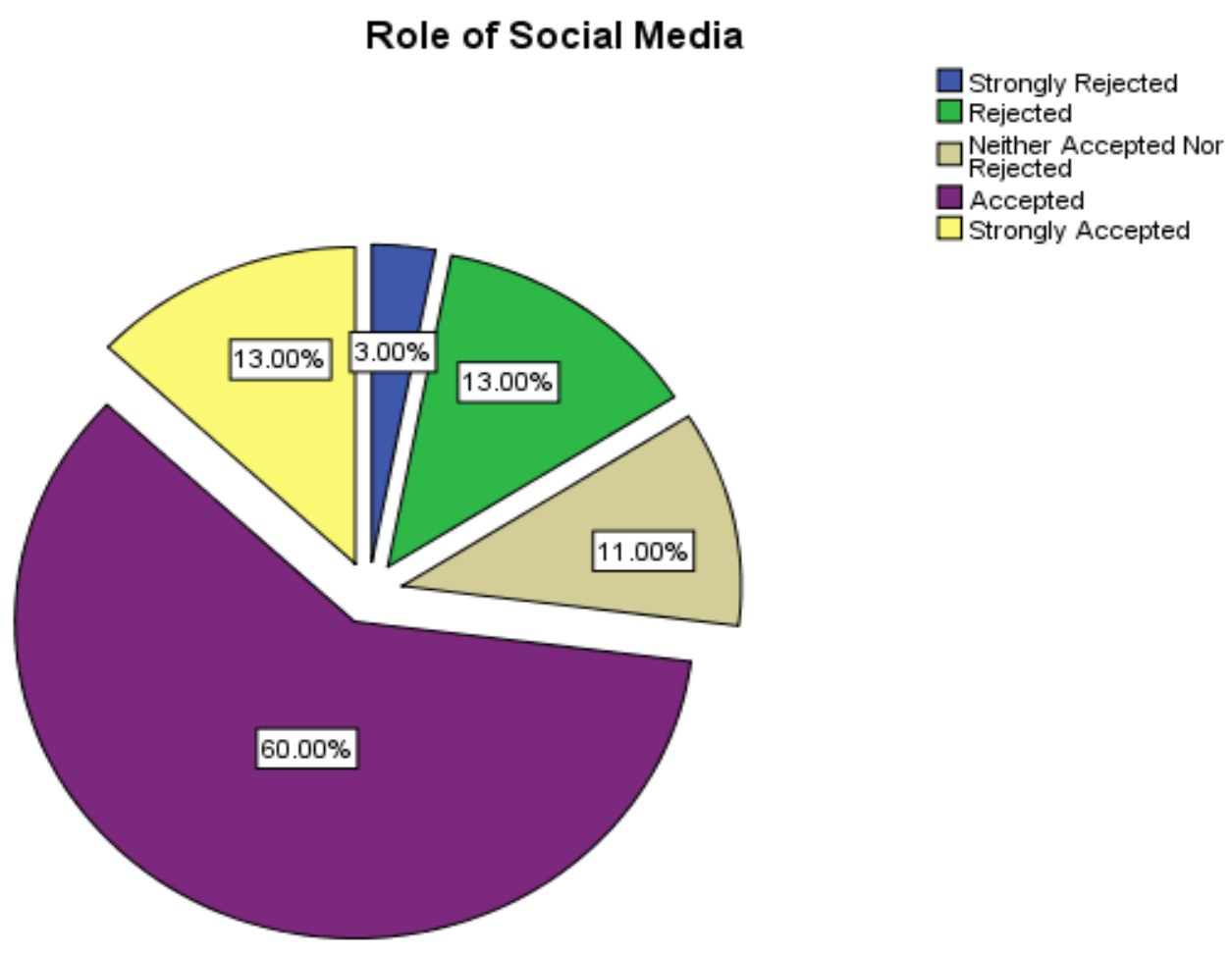

Figure 2. Significant Role of Social Media

Table 4. Test Statistics

\begin{tabular}{lrr}
\hline & Dimension of Adjustment & Role of Social Media \\
\hline Chi-Square & $40.560^{\mathrm{a}}$ & $103.400^{\mathrm{b}}$ \\
df & 6 & 4 \\
Asymp. Sig. & .000 & .000 \\
\hline
\end{tabular}

a. 0 cells $(0.0 \%)$ have expected frequencies less than 5 . The minimum expected cell frequency is 14.3 .

b. 0 cells $(0.0 \%)$ have expected frequencies less than 5 . The minimum expected cell frequency is 20.0 .

Hypothesis Test Summary

\begin{tabular}{|c|c|c|c|}
\hline & Null Hypothesis & Sig. & Decision \\
\hline 1 & $\begin{array}{l}\text { The distribution of Dimension of Qne-Sample } \\
\text { Adjustment is normal with mean Kolmogorov- } \\
3.99 \text { and standard deviation } 1.555 \text { mimov Test }\end{array}$ & .002 & $\begin{array}{l}\text { Reject the } \\
\text { nuil } \\
\text { hypothesis. }\end{array}$ \\
\hline 2 & $\begin{array}{l}\text { The distribution of Role of SociaDne-Sample } \\
\text { Media is normal with mean } 3.67 \text { Kolmogorov- } \\
\text { and standard deviation } 0.96 \text {. Smimov Test }\end{array}$ & .000 & $\begin{array}{l}\text { Reject the } \\
\text { nuil } \\
\text { hypothesis. }\end{array}$ \\
\hline
\end{tabular}

Asymptotic significances are displayed. The significance level is .05 .

\section{Hypothesis}

H01: The opinion mining of expatriates are not significant towards adjustment

H0A: The opinion mining of expatriates are significant towards adjustment. 
H02: There is no significant relationship between factors of opinion mining and social media.

H2A: There is a significant relationship between factors of opinion mining and social media.

\section{Discussion}

Above data analysis and interpretation is based on the SPSS software at 0.05 significant level. The probability of statistics is 0.000 which is less than 0.05 significant level so the null hypothesis is rejected and the result is significant. The researcher concluded that the factors of opinion mining of expatriates General Adjustment are having 5\%, Interaction Adjustment $14 \%$, Work Adjustment 15\%, Psychological Adjustment 35\%, Socio-emotional $12 \%$, Support Availability 12\%, Instrumental Support Needs 7\%\&, Emotional, and Support Needs are the significant components for the expatriates adjustment.

The researcher also emphasized that the significant role of social media is having $60 \%$ are accepted that social media are playing a significant role to solve the problem of expatriates concerning their individuals and job perspectives. The probability of statistics of social media 0.000 which is less than 0.05 significant level, so the null assumption is rejected, and the result is significant. At this level, the researcher concluded that social media are playing one of the significant levels towards the adjustment of expatriates.

\section{Conclusion}

In this researcher paper, the researcher focused on the individual opining of expatriates and job factors of expatriates and the significant role of social media with the help of opinion mining of the individual employees at a different significant level. The researcher pointed out the individual factors and job factors of expatriates which are stated as general adjustment, interaction adjustment, work adjustment, psychological adjustment, socio-emotional, support availability, instrumental support needs, emotional, and support needs are significant towards the expatriate's adjustment. The probability of statistics of social media is also proved that it is one of the significant components for the expatriated adjustment concerning different opinion mining from the different expatriates. Finally, researcher concluded that individual factors of expatriates and social media are significant for the adjustment of expatriates.

\section{References}

Alan Fish \& Jack Wood (2006). A review of expatriate staffing practices in Australian business enterprises. The International Journal of Human Resource Management, 7(4), 846-865.

Chenyi Qin \& Yehuda Baruch. (2010). The impact of cross - cultural training for expatriates in a Chinese firm. Career Development International, 15(3), 296-318. https://doi.org/10.1108/13620431011053758

Edson Keyso de Miranda Kubo and Beatriz Maria Braga Lacombe. (2012). Rethinking adjustment and success in expatriation: an empirical research on Japanese expatriates in Brazil, Conference: 28th EGOS Colloquium, At Helsinki, Finland.

Hon Lam \& Jan Selmer. (2004). Are former "third - culture kids" the ideal business expatriates? Career Development International, 9(2), 109-122. https://doi.org/10.1108/13620430410526166

Hung-Wen Lee \& Ching-Hsiang Liu. (2007). An examination of factors affecting repatriates' turnover intentions. International Journal of Manpower, 28(2), 122-134. https://doi.org/10.1108/01437720710747956

Jaime Bonache, (2005). Job satisfaction among expatriates, repatriates and domestic employees: The perceived impact of international assignments on work - related variables. Personnel Review, 34(1), 110-124. https://doi.org/10.1108/00483480510571905

Jan Selmer \& Hon Lam. (2004). Third - culture kids- Future business expatriates? Personnel Review, 33(4), $430-445$. https://doi.org/10.1108/00483480410539506

Jan Selmer. (1997). Differences in leadership behavior between expatriate and local bosses as perceived by their host country national subordinates. Leadership \& Organization Development Journal, 18(1), 13-22. https://doi.org/10.1108/01437739710156240

Julia Richardson \& Steve McKenna. (2006). Exploring relationships with home and host countries: A study of self-directed expatriates. Cross Cultural Management: An International Journal, 13(1), 6-22. https://doi.org/10.1108/13527600610643448 
Kimmo Riusala \& Vesa Suutari. (2000). Expatriation and careers: perspectives of expatriates and spouses. Career Development International, 5(2), 81-90. https://doi.org/10.1108/13620430010318945

Li-Yueh Lee. (2010). Multiple intelligences and the success of expatriation: The roles of contingency variables. African Journal of business Management, 4(17), 3793-3804.

Li-Yueh Lee. (2018). An Investigation Of The Moderating Effects Of Psychological Contract For The Influence Of Eq And Cq On Expatriate Performance, Department of International Trade.

Lyn Glanz. (2003). Expatriate stories: a vehicle of professional development abroad? Journal of Managerial Psychology, 18(3), 259-274. https://doi.org/10.1108/02683940310465261

Ma Eugenia Sánchez Vidal, Raquel Sanz Valle \& Ma Isabel Barba Aragón. (2010). Analysis of the repatriation adjustment process in the Spanish context. International Journal of Manpower, 31(1), 21-41. https://doi.org/10.1108/01437721011031676

Min Hyounae, P. Magnini Vincent \& Singal Manisha. (2013). Perceived corporate training investment as a driver of expatriate adjustment. International Journal of Contemporary Hospitality Management, 25(5), 740-759. https://doi.org/10.1108/IJCHM-May-2012-0079

Nana Yaw Oppong. (2013). The Good and the Bad of Structural Adjustment Programme in Africa: Evidence from Ghanaian Gold Mining Industry. International Journal of Business and Behavioral Sciences, 3(10), 27-41.

Roblyn Simeon \& Keiko Fujiu. (2000). Cross-cultural adjustment strategies of Japanese spouses in Silicon Valley. Employee Relations, 22(6), 594-611. https://doi.org/10.1108/01425450010379216

Steve McKenna. (2010). Adjustment" of the independent expatriate - a case study of Doug. Qualitative Research in Organizations and Management: An International Journal, 5(3), 280-298. https://doi.org/10.1108/17465641011089881

Vesa Suutari \& David Burch. (2001). The role of on - site training and support in expatriation: existing and necessary host-company practices. Career Development International, 6(6), 298-311. https://doi.org/10.1108/EUM0000000005985

Vesa Suutari, Kusdi Raharjo \& Timo Riikkilä. (2002). The challenge of cross-cultural leadership interaction: Finnish expatriates in Indonesia. Career Development International, 7(7), 415-429. https://doi.org/10.1108/13620430210449948 